\title{
CRISIS DOMINATION AND CRISIS RESPONSE STRATEGIES OF INDONESIAN STATE- OWNED COMPANIES IN ONLINE MEDIA DURING JANUARY 2007 - JULY 2018
}

\author{
Rifgie Indiraswari ${ }^{\star}$, Postgraduate Student \\ Magister Program of Communication Science, Faculty of Social and Political Sciences, \\ University of Brawijaya, Indonesia \\ Rachmat Kriyantono, Wulandari Maulina Pia \\ Department of Communication Science, Faculty of Social Political Sciences, \\ University of Brawijaya, Indonesia \\ *E-mail: rifgie.indiraswari@gmail.com
}

\begin{abstract}
A crisis is an unexpected event that threatens the important expectations of stakeholders and has a serious impact on organizational performances. By understanding the type of crisis that exists, it will help organization to choose the right crisis response strategy. This study uses positivistic paradigm with quantitative method through content analysis for collection data techniques. The purpose of this study is to describe domination of crisis types and crisis response strategies of state-owned companies in Indonesia, PT. Pertamina (Persero) and PT. Telkom Indonesia (Persero) Tbk, which was reported by detik.com within 10 years. Content analysis was conducted on total of 189 news crisis obtained from news on detik.com for the period Januari 2007 - July 2018. The results of the study based on Situational Crisis Communication Theory by Coombs and Holladay (2002). This study shows that there are different styles between two companies in responding to the current crisis situation.
\end{abstract}

\section{KEY WORDS}

Content analysis, crisis type, crisis response strategy, situational crisis communication theory, state-owned companies, Indonesia.

As a manager, consultant, or researcher cannot rule out the crisis which occurs in the organization, even it is in small forms, such as pollution, industrial accidents, and product defects (Mitroff, Shrivastava, and Udwadia, 1987). According to Regester and Larkin (2005), a crisis is an event which makes the organization as the public spotlight and has the potential to be disliked. Companies which experience a crisis are defined as companies which get unexpected events that cause problems and threaten the priority goals of an organization (Seeger, Sellnow, and Ulmer, 1998 in Dean, 2004).

There are several statements from different writings which reveal that the crisis experienced by an organization can affect the reputation of an organization. Dean (2004) states that the crisis experienced by an organization will have an impact on negative publicity so that it can threaten the reputation of the organization. Meanwhile, Winkleman (1999) states that the reputation of an organization is recognized as one of the resources which have high value and can affect the image of the organization. Besides being able to damage the reputation of an organization, it turns out that crises can also influence the behavior of stakeholders towards the organization (Dowling, 2002).

Rising crises have caused pressure on organizations in responding the crises so that crisis management is needed (Coombs, 2001). Crisis management aims to minimize the negative impact of an event through the preparation and implementation of several strategies and tactics (Kriyantono, 2015, p. 220). Sturges (1994, p. 298) in his paper mentions three areas of crisis management, namely preparation for crisis challenges, organizational and public behavior during the crisis period, and the importance of communication between organizations and their public during the crisis. 
Sturges (1994) emphasizes the importance of communication with the public during a crisis has an aim to provide the correct information and it is expected to form positive opinions after the crisis. Coombs (1999) also emphasizes that when an organization faces a crisis, the organization needs to communicate with its public as a form of crisis response. To protect the reputation of an organization, a situational approach is needed in choosing a crisis response strategy to find out what the organization must say and do (Coombs and Holladay, 2002). One of the theories of a comprehensive situational approach for responding the crises and protecting the organizations is Situational Crisis Communication Theory (Coombs and Holladay, 2002).

The basic assumption of Coombs (2007) in formulating Situational Crisis Communication Theory (SCCT) is an advantage in understanding the crisis communication which can protect the reputation of the organization as an asset during a crisis. Coombs (2007) states that the SCCT provides an evidence-based framework which has purpose to understand how to protect an organization's reputation through post-crisis communication. What is believed in this theory is that a crisis manager in an organization must be able to understand the crisis situation well, including assessing the level of threats caused by the crisis, to determine crisis management strategies which can maximize reputation protection (Coombs, 2007). SCCT has a crisis response strategy, which is divided into two parts, namely the primary crisis response strategies and secondary crisis response strategies (Coombs, 2007, p. 170). In the SCCT study is divided into 3 crisis divisions, namely victim clusters, accidental cluster, and intentional clusters (Coombs and Holladay, 2002, p. 179).

Barton (1990) explains that the crisis stage experienced by an organization can be seen from the news in the media around. Barton (1990, p. 7) states that the effectiveness of a relation among the media is one of the important aspects of crisis management. In addition, Kriyantono and McKenna (2017, p. 9) also mention that one of the principles which must be applied in public relations theory in Indonesia is to tell the truth. From the research conducted by Barton (1990), many cases stated that the organization was less alert and unavailable in providing information to the media, from this situation the public opinion formed would tend to be negative. Coombs (2006) also mentions the importance of seeing how media frames the crisis faced by organizations because it will affect public perceptions and the image of the organization.

This content analysis study will look at how media coverage will be reflected in crisis dominance and crisis response strategies used by an organization. The media that will be chosen by researchers is online media, namely detik.com. There are two selected subjects of state-owned companies in this study, namely PT. Pertamina (Persero) and PT. Telekomunikasi Indonesia (Persero) Tbk. Analysis of the news will be selected through citations, either directly or indirectly, expressed by the internal parties of the company which are restated by the media.

Furthermore, this research is carried out by referring to the two main problem formulations. First, the dominant type of crisis which occurred in the two Indonesian stateowned companies in the period of January 2007 - July 2018. Second, the dominant crisis response strategy was most often used by the two Indonesian state-owned companies.

\section{LITERATURE REVIEW}

So many writings define the meaning of the crisis, Rodriguez, Quarantelli, and Dynes (2007) mention that crises have become part of human experience since humans lived in groups. From the definitions cited by Coombs and Holladay (2010, p. 18-19), they define crises as perceptions of unexpected events which threat to the important expectations of stakeholders and have a serious impact on organizational performance and produce negative results. Therefore action is needed to prevent crises or minimize damage caused by crises. Coombs and Holladay (2002) in his writing also explain that before deciding on a crisis response strategy to be used, a crisis manager needs to identify the type of crisis, then by knowing the type crisis faced, it aims to find out the level of crisis responsibility which 
would become a public attribute in a crisis situation. Coombs (2007) identifies 3 crisis clusters based on the attribution of crisis responsibility from the type of crisis

- The victim cluster: this cluster has a low level of responsibility attribution to the crisis. This shows that organizations are as the victims of an event, such as natural disasters, workplace violence, rumors, and so on;

- The accidental cluster: this cluster has a minimal level of responsibility attribution to the crisis. This shows that the events which cause the crisis occur accidentally and are out from the control of the organization, such as accidents due to technical errors, product damage due to technical errors, and challenges;

- The intentional cluster: this cluster has the highest level of responsibility for crisis. This shows the existence of organizational errors is considered done intentionally, such as accidents due to human error, product damage due to human error, and organizational misdeeds.

In this study, the researcher will describe the crisis response strategy which refers to the SCCT theory. SCCT is a theory developed by Coombs and Holladay (2002) through their writing entitled Helping Crisis Managers Protect Reputational Assets: Initial Tests of the Situational Crisis Communication Theory. This SCCT is a development from the previous Coombs' (1995) study which discusses matching crisis response strategies and crisis situations. Coombs (1995) in his writing suggests that the formulation of crisis response strategies is an important aspect that must be mastered by organizational management. Assessment of crisis situations is a factor which mostly affects the choice of communication strategies (Ware and Linkugel, 1973; Coombs, 1995; Coombs \& Holladay, 1996). Attribution theory will be the basis in explaining the relationship between crisis response strategies and crisis situations (Coombs, 1995, p. 448). Contributions created in the public mind will create the perception that the organization is responsible but not for the crisis. Coombs (1995, $p$. 449) emphasizes that correct attribution is when a perception is created and the crisis is caused by external parties, is uncontrolled, and has various causes. Clarification related to an event by an organization or individual can influence public attribution in two ways, namely a message which can shape how the way the public sees that there are three public dimensions and a message which can influence public feelings created by attribution (Coombs \& Holladay, 1996, p. 282). In other words, the message in a communication is said to be able to influence someone's attribution or the next feeling attached to that attribution.

The SCCT is built from a number of assumptions, one of which is to believe that an organization's reputation includes high-value resources that can be threatened by the existence of a crisis (Coombs \& Holladay, 2002). The SCCT offers a framework for understanding these dynamic patterns. The framework offered by SCCT is based on the evidence to understand how to maximize reputation protection during and after a crisis. A crisis manager, before choosing a crisis response strategy will identify the type of crisis first. The results of the identification will be used by the public as a frame to interpret the event. From the frame formed in the minds of the public, it will create attributions related to the crisis faced by the organization. After assessing the level of crisis responsibility based on the type of crisis, crisis managers will determine crisis response strategies based on these assessments. This SCCT study demands a theoretical relationship between crisis situations and crisis response strategies. The following is the SCCT study reference crisis response strategy (Coombs, 2007):

Primary Crisis Response Strategies, namely strategies which contain the denial. Consists of:

- Attack the accuser: crisis managers face the people or groups of people who think something is wrong with the organization;

- Denial: crisis managers insist that there is no or no crisis;

- Scapegoat: crisis managers blame people or groups of people outside the organization for the crisis;

- Excuse: crisis managers minimize organizational responsibility by denying the intention to harm the organization and / or inability to control a crisis-triggering event; 
- Justification: crisis managers minimize the damage felt by the crisis. In this case rebuilding the crisis response strategy;

- Compensation: crisis managers offer money or other gifts to victims;

- Apology: crisis managers show a sense of full responsibility for the occurrence of a crisis and ask for apologize from stakeholders.

Secondary Crisis Response Strategies, namely strategies that broadly seek strength or support. Consists of:

- Reminder: remind stakeholders about the good performance of the organization in the past;

- Innovation: crisis managers give praise to stakeholders and or remind them of good performance by the company;

- Victimage: crisis managers remind stakeholders that the position of the organization is also a victim of the crisis.

Coombs (2006) reviews the study of how stakeholders see that the selection of crisis response strategies can be identified through the SCCT. From his study, Coombs (2006, p. 253-254) proves that the denial, attack the accuser, and scapegoat strategies fall into groups when the organization believes that no crisis occurs, excuse and justification strategies are included in the group when organizations try to minimize responsibility for events, and the strategies of compensation, apology, reminder, ingratiation, and victimage fall into groups when the organization has a high responsibility for events. The accuracy of choosing a crisis response strategy with assessment of crisis situations will result in maximum success in crisis management (Coombs \& Holladay, 2002).

Heider (1958 in An and Gower, 2009) states that people's perceptions and opinions about an event depend on information which appears around them. In addition, Fombrun and van Riel (2004) also state that organizational reputation is formed from information obtained by stakeholders. Carton (1990, p. 7) emphasizes that one important and crucial aspect of crisis management is the effectiveness of the relationship between organization with the media.

\section{METHODS OF RESEARCH}

This research refers to the positivistic paradigm. Bungin (2005) describes the criteria of science having a positivistic view that it is objective (theory must be value-free), phenomenalism (science is only focused on the observed universe), reductionism (the universe is reduced to be observable as the hard facts), naturalism (universe is a moving object mechanically). Regarding the positivistic approach, this study will use quantitative methods. Robert Donmover (in Given, 2008) mentions that quantitative research is research which has an approach through the empirical studies to collect, analyze, and display data in numerical form on the narrative. This will be descriptive research which has a purpose that to describe the dominance of the crisis and the crisis response strategies exist in the two Indonesian SOE companies.

This study will use a quantitative type of research with quantitative content analysis techniques by collecting data from events or events that have already taken place. Favorite (2015) concludes that the purpose of content analysis is to obtain the strong descriptions of the communication studied samples. Supported by the study of Martono (2014, p. 95) which mentions one of the objectives of content analysis is to describe dominance in communication content.

The sampling method used in this study was simple random sampling which received a total of 189 news stories from the two companies, PT. Pertamina (Persero) totaling 116 news and PT. Telkom Indonesia (Persero) Tbk totalling 73 news in the reporting period from January 2007 - July 2018. Furthermore, news samples will be coded by researchers and two other coders using coding sheets. The categorization which becomes the reference in coding data is as follows:

- Type of crisis: victim cluster (1), accidental cluster (2), intentional cluster (3); 
- Crisis response strategy: attack the accuser (1), denial (2), scapegoat (3), excuse (4), justification (5), compensation (6), apology (7), reminder (8), ingratiation ( 9), victimage (10).

The reliability test method used by researchers in this study is intercoder reliability, which uses two or more coders to check the consistency of coding (Martono, 2014). The study uses three coders including researchers. The research reliability test refers to the recommendations of content analysis research by Nurhayati, Ardianto, and Komariah (2000) which use the Pearson contingency coefficient formula (C).

$$
C=\sqrt{\frac{\chi^{2}}{N+\chi^{2}}}
$$

To find out the percentage of agreement coding, it uses the formula IR $=(1-C) \times 100 \%$. The level of news sample agreement for PT. Pertamina (Persero) amounting to $99.96 \%$ and the level of agreement coding for news samples of PT. Telkom Indonesia (Persero) Tbk amounting to $99.54 \%$. In this study we will use a frequency distribution table to process the data obtained by researchers. Through the frequency distribution table, it will help researchers to read the percentage spread of each category. Then it will be moved in the form of a percentage namely numbers and the dominant item appeared.

\section{RESULTS AND DISCUSSION}

The results of research conducted by researchers to get an the dominance idea of the crisis type experienced by Indonesian state-owned companies were analyzed by the news published in detik.com from two companies, namely PT. Pertamina (Persero) and PT. Telkom Indonesia Tbk. Analysis which has been done on 116 news about PT. Pertamina (Persero) and 73 news about PT. Telkom Indonesia Tbk, obtained the results that the crisis reporting for PT. Pertamina (Persero) belongs to the victim cluster crisis type totaling $43.1 \%$, followed by the intentional cluster type totaling $32.8 \%$, and finally the accidental cluster type totaling $24.1 \%$. And, the results of the crisis reporting for PT. Telkom Indonesia (Persero) Tbk is classified as a crisis type cluster totaling $54.8 \%$, followed by the type of accidental cluster totaling $38.4 \%$, and the last type intentional cluster totaling $6.8 \%$.

The results of the researcher's calculations for the crisis response strategy category, the three dominant crisis response strategies used by PT. Pertamina (Persero) published in detik.com's online media portal is a crisis report which uses denial crisis response strategies of $29.3 \%$, followed by justification of $19.0 \%$, and finally scapegoat of $15.5 \%$. As well as the results of the researcher's calculations for the crisis response strategy category, the three dominant crisis response strategies used by PT. Telkom Indonesia (Persero) Tbk which is published in detik.com's online media portal is a crisis report which uses an excuse crisis response strategy of $26.0 \%$, followed by denial strategy of $23.3 \%$, and finally justification of $13.7 \%$.

\section{CONCLUSION}

The dominance of the type of crisis faced by PT. Pertamina (Persero) based on the results of an analysis of the news in detik.com in the period of 10 years from January 2007 July 2018 is a type of victim cluster crisis. Just like PT. Pertamina (Persero), the dominance of the type of crisis faced by PT. Telkom Indonesia Tbk based on the analysis of news on detik.com in the 10 years period from January 2007 - July 2018 is also a type of victim cluster crisis. When referring to the crisis type theory formulated by Coombs (2007), the two Indonesian state-owned companies are more often faced the crises which cannot be controlled by the company. This shows that the two Indonesian state-owned companies have low or minimal levels of responsibility attribution to the crisis. 
Regarding the description of the most dominant crisis response strategy used by the two Indonesian state-owned companies, PT. Pertamina (Persero) and PT. Telkom Indonesia (Persero) Tbk, are within 10 years period from January 2007 - July 2018. For PT. Pertamina (Persero), the most dominant crisis response strategy used is denial strategy. This strategy is a form of rejection or denial of the company against the crisis. Meanwhile, the most dominant crisis response strategy is carried out by PT. Telkom Indonesia Tbk is an excuse strategy. This strategy is a business enterprise by minimizing corporate responsibility by denying the company's inability to respond to the crisis. When it is associated with the Coombs (2007) of SCCT theory, organizations which have cluster victim crisis situations are recommended to use denial crisis response strategies. Whereas, the use of excuse crisis response strategies is more recommended for organizations in the cluster accidental.

\section{REFERENCES}

1. Barton, L. (1990). Crisis management: Selecting communications strategy. Management Decision, 28(6), 5-8.

2. Barton, L. (1993). Crisis in organizations: Managing and communicating in the heat of chaos. Cincinnati, $\mathrm{OH}$ : College Divisions South-Western Publishing.

3. Barton, L. (2001). Crisis in organizations II (2nd ed.). Cincinnati, OH: College Divisions South-Western Publishing.

4. Coombs, W. T. (2007). Protecting organizations reputations during a crisis: the development and application of situational crisis communication theory. Corporate Communication Review, 10(3), 163-176.

5. Coombs, W. T. (2015). Ongoing Crisis Communication: Planning, Managing, and Responding (fourth edition). California: Sage Publishing.

6. Coombs, W. T. (2010). Why a concern for apologia and crisis communication? Corporate Communication: An International Journal, 15(4), 337-349.

7. Coombs, W. T., Holladay, S. J. (2002). Helping crisis managers protect reputational assets: initial test of the situational crisis communication theory. Management Communication Quarterly, 16(2), 165-186.

8. Coombs, W. T., Holladay, S. J. (2006). Unpacking the halo effect: reputation and crisis management. Journal of Communication Management, 10(2),123-137.

9. Coombs, W. T., Holladay, S. J. (2010). The Handbook of Crisis Communication. UK: Blackwell Publishing Ltd.

10. Dowling, G. (2002). Creating Corporate Reputations: Identity, Image, and Performance. New York: Oxford University Press.

11. Krippendorff, K. (2004). Content Analysis: An Introduction to Its Methodology. California: Sage Publications.

12. Kriyantono, R. (2014). Teknik Praktis Riset Komunikasi . Jakarta: Prenada Media.

13. Kriyantono, R. (2014). Teori Public Relations Perspektif Barat dan Lokal: Aplikasi Penelitian dan Praktik. Jakarta: Kencana.

14. Kriyantono, R. (2015). Public Relations, Issue \& Crisis Management: Pendekatan Critical, Etnografi Kritis \& Kualitatif. Jakarta: Kencana.

15. Kriyantono, R., McKenna, B. (2017). Developing a Culturally-Relevant Public Relations Theory for Indonesia. Malaysian Journal of Communication, 33(1), 1-16.

16. Martono, N. (2014). Metode Penelitian Kuantitatif: Analisis Isi dan Analisis Data Sekunder. Jakarta: Rajawali Pers.

17. Mitroff, I. I. (1994). Crisis management and environmentalism: a natural fit. California Management Review, 36(2), 101-113.

18. Mitroff, I. I., Shrivastava, P., Udwadia, F. E. (1987). Effective crisis management. The Academy of Management Executive, 1(4), 283-292.

19. Riffe, D., Lacy, S., Fico, F. (2014). Analyzing Media Messages: Using Quantitative Content Analysis in Research. New York: Routledge.

20. Sturges, D. L. (1994). Communicating through crisis: a strategy for organizational survival. Management Communication Quarterly, 7(3), 297-316. 